\title{
KATONA Péter
}

\section{Tehetséggondozó portfolió a kollégiumpedagógiai gyakorlatban}

Véleményem szerint a tehetségek felismerése, azonosítása és a személyiségközpontú tehetséggondozás központi helyet kell, hogy elfoglaljon a határozott jövőképpel rendelkező és szervezeti kultúráját tudatosan alakítani kívánó kollégium pedagógiai tevékenységrendszerében.

A következőkben a tehetséggondozás hazai kollégiumpedagógiai megjelenésérôl lesz szó. A téma - bár a teljességre törekvés jegyében igényelné -, e cikk tartalmi és terjedelmi kereteit meghaladó nagysága nem teszi lehetővé, hogy nemzetközi kitekintésben tárgyaljam. Ezért e helyen csak jelzésszerűen említem meg, hogy a középiskolai kollégiumi rendszernek és benne a tehetséggondozásnak nincs egységes nemzetközi gyakorlata.

\section{Tehetséggondozás a köznevelési intézményrendszerben}

A tehetséggondozásra nem tekinthetünk úgy, mint egy elvont, eszmei magasságokban lebegő fogalomra: sokkal inkább a köznevelés teljes intézményrendszerét átszövő, annak szerves részét képező folyamatra, program- és tevékenységrendszerre. Ennek megfelelően az óvodától az általános és a középiskolán át a kollégiumig és - a Nkt. 18. \(2) bekezdésének j) pontja által is erre kötelezett - pedagógiai szakszolgálatokig minden intézménynek megvan benne a sajátos helye és szerepe. Fontos tisztában lennünk azzal, hogy a tehetségekkel való foglalkozás - amellett, hogy a legszebb tanári feladat - még a pedagógia egyéb területeinél is nagyobb egyéni felelősséget helyez a pedagógusra, aki egyszerre szembesül oktatói, nevelői, személyiségfejlesztői, mentori és tréneri feladatokkal, miközben ezek esetleg nem mindegyikére van képesítése. Emellett pontosan ismernie kell az alapfogalmak jelentését (mi a tehetség?, ki a tehetséges? stb.).

\section{A tehetség fogalma és összetevöi}

A tehetség fogalmát könyvtárnyi irodalom igyekszik definiálni, így itt csak az általam legfontosabbnak ítélt momentumokat ragadom ki.

A legkorábbi meghatározások a tehetséget az átlagon felüli intellektuális képességekel azonosították (Terman, 1924). Késóbbi kutatók rámutattak, hogy a tehetség kibontakozaásában alapvető szerepe van a környezeti tényezókenek és az önképnek (Tannenbaum, 1983), s a kiemelkedő képességek nem okvetlenül vezetnek az átlagot meghaladó teljesitményhez (Gagné, 1993). Már a kutatások korai szakaszában kiderült, hogy nagyon fontos a kreativitás, az intuíció, a motiváció, az akaraterô és az elkötelezettség szerepe (Révész G., 1918), s ezeket felhasználva alkothatták meg az ún. kiszélesítő, többdimenziós tehetségmodelleket (Ren₹ulli, 1978). Azt is kimutatták, hogy az értelmi képességek és az alkotókészség nem szükségszerủen járnak párban (Kitano és Kirby, 1986), s a tehetséget a kreatív személyiségjegyek különböztetik meg az egyszerűen jó intellektusúaktól (Landau, 1980). Önmagában valamely kiemelkedő képesség csak tehetségigéretté teszi az egyént (Orosz R., 2010), a kibontakozáshoz a külsó tényezóke (család, iskola, társak) hozzájárulása is szükséges (Mönks és Knoers, 1997). Emellett a tehetség kulturálisan meghatározott és az egyén élete során is változó (Szentmihályi és Robinson, 1986), folyamatos tanulási folyamat. A legkomplexebb, ún. 2X4+1 faktoros tehetségmodell Czeizel Endre (1997) nevéhez füződik: négy adottság (általános értelmi, speciális mentális, kreativ és motivációs) mellett négy külső hatást (család, iskola, kortárs csoport és

\footnotetext{
${ }^{1}$ Angolszász országokból jól ismert az ottani felsőoktatásra jellemző college-rendszer. Előfordulnak ott a középiskolás korosztályt is képző bentlakások, amelyek náluk szorosan kapcsolódnak az elitképzéshez (pl. Eton). A nemzetközi (kompetencia-alapú) mérésekben rendre jól szereplő Finnországban ugyanakkor egyáltalán nincsenek középiskolai kollégiumok, holott azt hihetnénk, hogy azt már csak az állam területi kiterjedtsége és településhálózata is indokolná (ehelyett a diákok szervezett, iskolabuszos utaztatása és a távoktatás jellemző).
} 
társadalom) említ, valamint beemeli a „sors-faktort” is a rendszerbe (élettartam, egészség, véletlenek stb. szerepe). ${ }^{2}$

„Tehetségesnek tehát azok tekinthetők, akik kiváló adottságaik alapján magas szintű teljesítményre képesek az élet bármely területén” (Balogh L., 2007). ${ }^{3}$

\section{A tehetséggondozás folyamatának szakaszai}

A tehetségígéretből akkor válik tehetség, ha a hangsúlyt a fejlődésre és a fejlesztésre téve, a tehetséggondozást folyamatként fogjuk fel. Már Maslow kiemelte, hogy minden emberben - azaz, tehetjük hozzá, a tehetségígéretekben is - ott van a fejlődésre és az önmegvalósításra való igény. A gyermek környezete előtt áll az a feladat, hogy biztosítsa a tehetség kibontakoztatásának feltételeit: Gagné ún. differenciált adottság-és tehetségmodellje szerint az egyén akkor válhat produktivv tehetséggé, ha a kiemelkedô genetikai adottságokat a tanulási, fejlesztési folyamatok, valamint személyen belüli és a kedvező környezeti hatások katalizálják. ${ }^{4}$

A tehetséggondozás folyamatának első szakasza a tehetség azonosítása, a tehetségígéret felismerése. A tehetséggondozás kulcsfontosságú pillanata ez, hiszen hiánya vagy pontatlan múködése tehetségek elkallódásához vezethet. A tehetségazonositás akkor lehet a legpontosabb, ha komplex módszerekkel végzik: ezek közül a legismertebb az objektív tanári jellemzés, a célirányos tesztek és felmérések, kérdőívek felhasználása, továbbá a szülői és iskolapszichológusi vélemény kikérése.

A következő fázis a gyorsitás: korai iskolakezdést, évfolyam-összevonást, korai felsőoktatásba kerülést jelenthet. Megjegyzendő, hogy abban az esetben, ha a környezeti tényezők (pl. a családi, iskolai háttér) nem voltak megfelelőek, a gyorsítás felzárkóztatással, szintrehozással is megvalósulhat (pl. az időben lassításnak tűnő, de hosszútávon megtérülő „nulladik”, előkészítő osztály).

Elkeïlönités: a tehetséges tanulók összeválogatása, szegregálása a többiektől kedvezően hathat teljesítményükre, ám hátrányai miatt inkább a gazdagítás és dúsítás alkalmazása ajánlott. A gazdagitás a tehetséggondozás legfontosabb, a tehetséggondozás teljes tartama alatt jelen lévô eleme, amely egyaránt lehet mélységi, tempóban történő, tartalmi jellegű és a kreatív és kritikus gondolkodás ösztönzésére irányuló. Képzett, felkészült tanárokkal és professzionális szakmai programokkal valósítható meg; jellemző szervezeti formái: differenciált tanórák, szakkörök, fakultációk, önképzőkörök, egyéni és csoportmunka, versenyek, táborok, projektek, speciális osztályok, hétvégi iskola. ${ }^{5}$

\section{A tehetséggondozás intézményesülése}

Fontos alapeleme a jelenlegi köznevelési rendszernek, hogy a terület jogi alapjait biztosító Nkt. 62 . \ (1) bekezdésének a) és b) pontja a tehetséggondozást minden pedagógus feladatává és kötelességévé teszi, míg a törvény 3. számú melléklete szerint a kollégiumokban kívánatos a tehetségfejles:tố tanár végzettséggel rendelkező pedagógusok alkalmazása.

\footnotetext{
2 Mezei Anna-Polonkai Mária-Schmercz István: Sajátos pedagógiai, pszichológiai ismeretek. BME GTK APPI Műszaki Pedagógiai Tanszék, Budapest, 2012. 161. p, p. 42-56. és Inántsy-Pap Judit-Orosz Róbert-Pék Győző-Nagy Tamás: Tehetség és személyiségfejlesztés. Magyar Tehetségsegítő Szervezetek Szövetsége, 2010. 139. p., 51. p. Teljességében kifejti: Czeizel Endre: Sors és tehetség. Urbis, 2004. 242. p.

${ }^{3}$ Balogh László: Elméleti kiindulási pontok a tehetséggondozó programokhoz: A Nemzeti Tehetségsegítő Tanács 2007. január 5-6-i tanácskozása. Mi a tehetség? http://tehetseg.hu/mi-tehetseg (utolsó lekérdezés: 2014. március 16.). Kiemelés tőlem. A képesség kiemelése azért hangsúlyos, mert az önmagában még nem garantálja a kiemelkedő teljesítményt. Manapság vita van a tehetséggondozás szakemberei között arról, hogy azt a korábbi premisszát fogadjuk-e el alaptételként, hogy igazán tehetséges csak a népesség nagyon kis hányada, vagy azt az újabban terjedő álláspontot, hogy a népesség igen nagy hányada tehetséges valamiben, csak azt a „,valamit” kell megtalálni és fejleszteni.

${ }^{4}$ Inántsy-Pap J. et al. id. m. 53. p.

${ }^{5}$ Polonkai M. et al. id. m. 56-61. p.
} 
Mára Magyarországon is kialakult a tehetséggondozás szervezeti-intézményi háttere, amely biztosítani tudja a módszertani innovációk terjedését, a tehetséggondozó múhelyek és intézmények kapcsolattartását, hálózatosodását és esetenként érdekvédelmét is.

A hazai tehetséggondozás teljes spektrumát felöleli, vagyis az állami, önkormányzati és civil tehetséggondozó programoknak egységes keretet ad az Országgyúlés 126/2008 (XII. 4.) határozatával megalapított és 20 évre létrehozott Nemreti Tehetség Program (NTP), amely az oktatásért felelős miniszter irányításával múködik. Finanszírozását központi költségvetési forrásokból és a Munkaerő-piaci Alapból támogatott Nemzeti Tehetség Alap végzi. ${ }^{6}$

A NTP megvalósítását és a tehetségek nyomon követését, több szempontú segítését az országos tehetséghálózat részét képező mintegy nyolcvan Tehetségsegitō Tanács biztosítja. Feladatuk a tehetségek felkutatása, fejlesztése, az erőforrások biztosítása és bővítése. A versenyszféra felé is nyitott helyi és térségi szintû konzultációs fórumok, amelyek területi és tematikus alapon egyaránt szerveződnek. 2013 decemberében 17.600 jogi személyiségú szervezet és 610 köztiszteletben álló magánszemély tagjuk volt. Munkájukat 2006 márciusától országos szinten a Nemzeti Tehetségsegitó Tanács (NTT) fogja össze, amely konzultatív szervezetként a kormány illetékes tárgyalópartnere. A NTT jogi képviselője a Magyar Tehetségsegitő Szervezetek Sqövetsége (MATEHETSz). A NTP feladatainak végrehajtása a kormányzat részéről 2011 tavasza óta az Oktatáskutató és Fejlesztó Intézzet (OFI) szervezeti keretei között történik. Az OFI Nemzeti Tehetségfejlesz̨tő Köapontjába (NTFK) tagozódik be a Nemzeti Tehetség Programiroda, amely a NTP körüli operatív feladatokat látja el, beleértve az Arany János Tehetséggondozó Programok koordinálását is. ${ }^{7}$

A tehetségüggyel kapcsolatos kormányzati feladatok segítésére 2009-ben létrejött a Nemzeti Tehetségügyi Koordinációs Fórum is, a mindenkori oktatásért felelős miniszter elnökletével. ${ }^{8}$ Az NTP megvalósulása új szemléletű, módszertani frissítésre és erősítésre törekvő pályázati programok keretében történt: 2009-2011 között a 3,4 milliárd forintból gazdálkodó Magyar Géniusz Integrált Tehetségsegitó Program, majd 2012-től 2014 tavaszáig a 2 milliárd forintos költségvetésű, a tehetségek közvetlen segítésére összpontosító Tehetséghidak Program által. Az Európai Unió hétéves fejlesztési ciklusaihoz igazodva 2014 és 2020 között a NTP feladatait a Talentum Program viszi tovább. ${ }^{9}$

\section{Esélyteremtés, felzárkóztatás és tehetséggondozás a kollégiumban}

Nézetem szerint a megfelelő szakmai programokkal felvértezett kollégiumok - összetett tevékenységrendszerük révén - kiválóan alkalmasak lehetnek annak a társadalmilag kiemelt jelentőségű feladatnak az ellátására, amit a társadalmi mobilitás biztosításának igénye jelöl ki. Ennek eszköze az esélyteremtés, amely feladat - pedagógiai tartalmát tekintve - két fó tevékenységrendszerre osztható: tehetséggondozásra és felzárkóztatásra. E tevékenységek összefüggéseit, egymáshoz való viszonyát és társadalmi szerepét a következő ábrával szemléltetem.

\footnotetext{
${ }^{6}$ SZJA-1\%-os felajánlásokat is fogad: 2009 óta a felajánlók száma 129 ezerről 350 ezerre, a felajánlott adóbevétel 870 millió forintról 1,4 milliárdra nőtt. Tóth Tamás: A bazai tehetséggondozás helyzete, intézményi feladatok. Előadás, elhangzott a Tehetséghidak Program Tudástranszfer Fórumán. TÁMOP 3.4.5, Szeged, 2014. március 11. A korábban indított programok, pl. az Új Tudás Program célja is az addigi (állami, önkormányzati, intézményi és civil) programok összefogása volt, főként az Új Magyarország Fejlesztési Terv forrásainak felhasználásával. Polonkai M. et al. id. m. 68. p.

7 A NTFK-hoz tartozik felsőoktatási tehetséggondozáshoz sorolható Országos Tudományos Diákköri Tanács titkársága is. http://www.ofi.hu/rolunk/ofi-rovid-bemutatasa/nemzeti (utolsó lekérdezés: 2014. március 16.).

8 Társelnöke a NTT elnöke, a Magyar Tudományos Akadémia elnöke és az Országgyúlés oktatási és tudományos bizottsága által delegált országgyúlési képviselő. Alapításáról az 1119/2009. (VII. 23.), múködésének jelenlegi szabályairól az 1372/2011. (XI. 8.) kormányhatározat rendelkezik. uo. 70. p.

9 Finanszírozásuk főleg a Társadalmi Mobilitás Operatív Programok különböző alprogramjai által történt. Fontos megemlíteni, hogy a programok és a rájuk fordítható források a felső- és a közoktatást érintő tehetséggondozás egészének közszféra általi finanszírozását jelentették.
} 


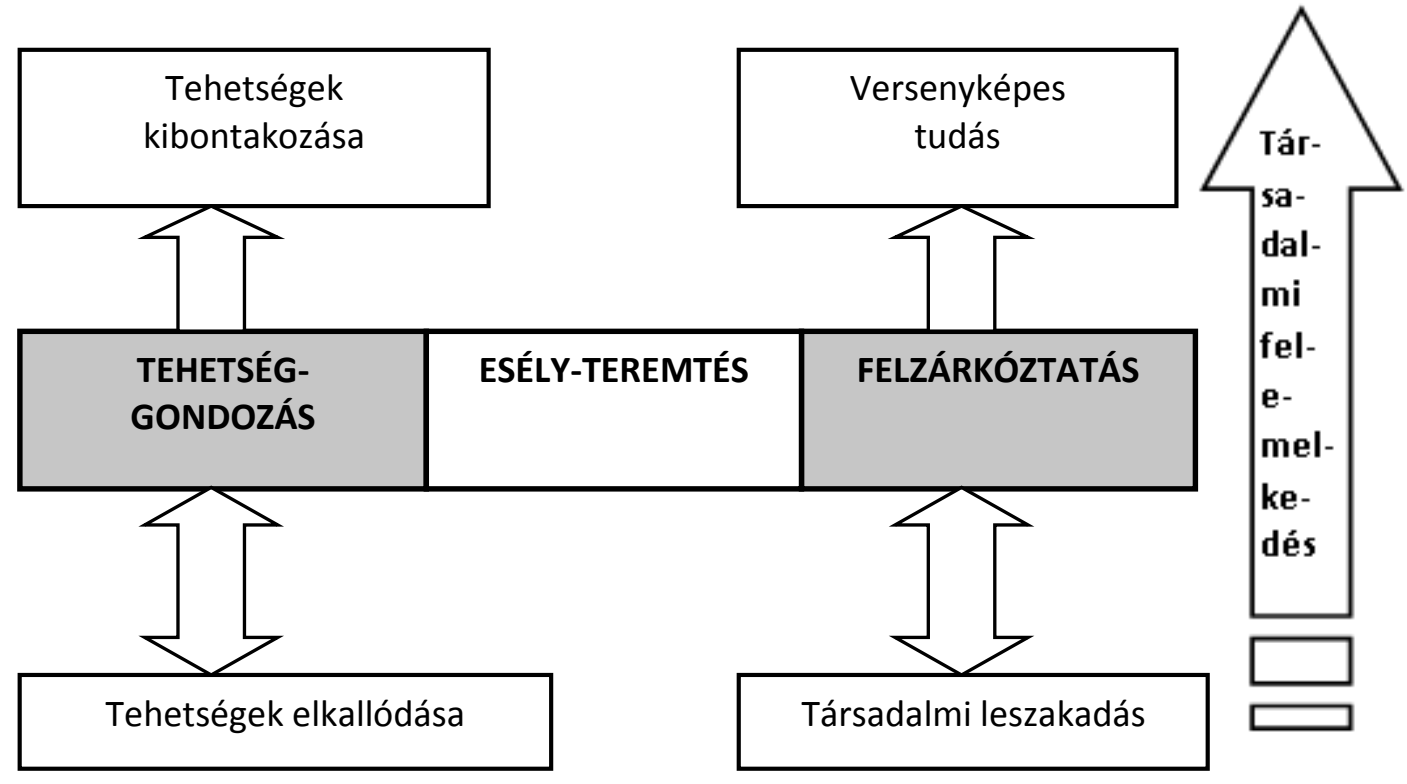

1. ábra. Az esélyteremtés és a társadalmi mobilitás kapcsolata (saját szerk.)

A kollégium mint a köznevelési intézményrendszer alappillére a magyar oktatástörténet során kulcsszerepet játszott a tehetséggondozásban és a vidéki, valamint a kevéssé tehetôs társadalmi rétegek gyermekei érvényesülésének elősegítésében, a társadalmi mobilitás biztosításában. ${ }^{10}$

Az oktatásban való részvétel a történelem során (a klasszikus ókori civilizációkat leszámítva) mindig a vezető társadalmi rétegek privilégiuma volt. A középkori Európában - az oktatás egyedüli letéteményeseként - kizárólag az egyház kínálta a felemelkedés esélyét az alávetett sorban élő, ám jó képességű fiúknak. Az újkorban aztán a társadalmi esélyteremtés és a tehetséggondozás sajátos színterévé a különböző (protestáns és katolikus) felekezeti fenntartású kollégiumok váltak. Kiemelkedő oktatási színvonaluk miatt Magyarországon a református kollégiumok, majd a jezsuita és piarista kollégiumok váltak híressé. ${ }^{11}$

Az államszocializmus időszakában központi akarat volt a munkás-paraszt származású fiatalok nagyarányú bejuttatása a felsőoktatásba. Ezt az 1948-as politikai fordulatot követően először adminisztratív eszközökkel (felvételi diszkriminációval) kívánták megoldani. Ez előbb színvonaleséshez, majd ahhoz vezetett, hogy az állami szigor késôbbi enyhülésével újra nagyobb arányban kerültek be az egyetemekre értelmiségi családokból származó hallgatók. A '60-as évekre az akkori oktatásirányítás számára nyilvánvalóvá vált, hogy „a munkásosztály vezető szerepe” az értelmiségi pályákon csak akkor várható, ha gyermekeiket már a középiskolákban felkészítik az egyetemi és főiskolai felvételikre, hiszen megfelelő előképzettség birtokában nagyobb eséllyel állhatnak helyt a felsőoktatásban. Mivel a legrosszabb szociokulturális közegből érkező, de tehetséges munkásfiatalok családi háttere sok esetben nem volt ideális, ennek a hatásnak a kompenzálására a fôvárosban az évtized közepén több speciális, kifejezetten a felsőoktatási felvételire felkészítő kollégiumot hoztak létre számukra. Ezek egyike volt a Táncsics Mihály Kollégium, a mai Táncsics Mihály Tehetséggondozó Kollégium (TMTK) egyik elődintézménye, ahol a cél érdekében saját módszertant és értékelési rendszert fejlesztettek ki.

\footnotetext{
${ }^{10}$ Jelenleg e kettős célnak kíván megfelelni az ország teljes területén jelen lévő Arany János Tehetséggondozó Program (AJTP), amely a középiskolák és kollégiumok együttmúködésének jó példája is.

11 Jellemző oktatástörténeti érdekesség, hogy esetükben nem a gimnáziumoknak volt kollégiumuk, hanem a kollégiumoknak gimnáziumuk. A magas szintű tantárgyi oktatás és az intézményi nevelés jelentőségének együttes hangsúlyozása nevelésfilozófiai szemléletet is kifejezett. E példaértékủ múlt emléke a mai elnevezésben pl.: Debreceni Református Kollégium Gimnáziuma és Diákotthona. Pedagógiai modelljük lényeges eleme volt, hogy a - döntően a köznépi származású - diákokat oktató tudóstanárok egyúttal nevelők is voltak a bentlakásos intézményben.
} 
Benedek I. (1997) tipizálta a hazai középiskolai bentlakásos intézményeket. Rendszerében eltérő sajátosságaik alapján - megkülönböztetett felsőoktatásra előkészítő kollégiumokat, szakkollégiumokat, speciális kollégiumokat, általános kollégiumokat, diákszállásokat és internátusokat. A mai értelemben vett tehetséggondozó feladatok ellátására az előbbi kettő, továbbá az internátus alkalmas. Az akkori Táncsics (pontosabban annak speciális felvételi felkészítő részlege) e rendszerben a felsôoktatásra elókészitö kollégium, többi részlege pedig az általános kollégium kategóriájának felelt meg. A TMTK tehetséggondozó tevékenységportfoliójának bővülését jelentette az AJTP elindítása 2000-től; a két esélyteremtő, tehetséggondozó program egyidejű jelenléte indokolta, hogy 2010-től az intézmény nevében is megjelenítse fő profilját. ${ }^{12}$

Módszertani kultúrájában az előkészítő kollégiumhoz hasonlítható, ám szakirányú felvételire felkészítő és személyre szabott tehetséggondozó feladatokat felvállaló, gimnáziumi helyett szakközépiskolai növendékekkel foglalkozó innovatív intézménytípusként jelent meg e rendszerben a szakkeollégium. Úttörő képviselője a budapesti Ady Endre Közgazdasági Szakkollégium (Fővárosi Gyakorló Kollégium) volt, amely ugyan - 60 évnyi múködés után, melynek utolsó harmadában (1992-tôl) alapító okirata szerint is szakkollégium volt - 2012-ben áldozatául esett a fővárosi intézményrendszer financiális „,racionalizálásának”, de módszertani múhely-jellege, kiadványai és szakmai újításai azóta is meghatározzák a kollégiumi tehetséggondozást és tanártovábbképzést. ${ }^{13}$

\section{Tehetséggondozó és felzárkóztató programok helyi gyakorlata}

Tehetséggondozás, felzárkóztatás - egy szóval: esélyteremtés - helyi gyakorlatáról írni - első hallásra - hálás feladatnak tűnik egy tehetséggondozó kollégium esetében. E tevékenységek összetettsége és sokrétűsége miatt azonban úgy gondolom, ezek részletes kifejtésére e helyen nincs mód. A kérdéskör megközelítését végezhetnénk a jogi-intézményi szabályozottság, a pedagógiai hozzáadott-érték megjelenése vagy a mérhető továbbtanulási és versenyeredmények felől egyaránt, ám e szempontok részletes bemutatása meghaladja e munka terjedelmi kereteit, s talán a szerző elméleti és módszertani felkészültségét is. Ezért a feladatra a továbbiakban inkább áttekintőrendszerező aspektusból adok választ: egyrészt felvázolom az intézményünkben folyó tehetséggondozó munka történeti előzményeit, bemutatom annak főbb jellegzetességeit és elhelyezem a Kollégiumi nevelés országos alapprogramja szakmai koordináta-rendszerének megfelelő foglalkozási rendszerben, másrészt rámutatok az annak fenntarthatóságával és fejlesztésével kapcsolatos problémakörre.

Véleményem szerint az eredményes tehetséggondozás és a hatékony felzárkóztatás - történjen az tanulmányi, múvészeti területen vagy a szociális kompetenciák vagy a személyiségfejlesztés terén - egyben mindig esélyteremtés is. Az e munka során befektetett pedagógiai hozzáadott-érték a tanuló életpályája során szakmai sikerekben, kibontakozásban, önmegvalósításban érik be. Sok esetben vezet egyéni felemelkedéshez, s mint ilyen, hozzájárul a társadalmi mobilitáshoz.

A tehetséggondozásban munkájával bármilyen részt vállaló pedagógus ebből a „globális” folyamatból lokális szinten leginkább annyit érzékel, hogy az évek során egy nehéz sorsú diákja a fizika OKTV-n harmadik helyezett lesz, egy másik sorra nyeri az irodalmi versenyeket és alkotói

\footnotetext{
${ }^{12}$ A szakmai előrelépés jövőbeni lehetőségét a jelenlegi jogi környezet a szakkollégiummá válás lehetőségével biztosítja. 13 A tipizálás részletesen: Benedek István: Kollégiumi neveléstan. A kollégiumi nevelés elmélete és gyakorlata. Országos Közoktatási Intézet, Budapest, 1997. 312. p, 31. p. Eszmei rokonság állapítható meg a felsőoktatás szakkollégiumaival, elsősorban a mentor-diák kapcsolat és a műhely-jelleg miatt - a középiskolai kollégium ettől még nem kópiája, hanem megalapozója a felsőoktatásinak. Az Ady Endre Közgazdasági Szakkollégiumhoz köthető a szakkollégiumi modell elmélete és gyakorlata (Benedek István (szerk.): Gondolatok a kollégiumban. Ady Endre Közgazdasági Szakekollégium, Budapest, 2002. 215. p.) és a Nemzeti kollégiumi alapprogram tematikájába is beépült, ill. abból kifejtett és levezetett, a tematikus alapprogrami foglalkozásokhoz felhasználható kidolgozott témakörök publikálása (Benedek István (szerk.): Gondolatok a kollégiumban II. Foglalkozási tervek az alapprogram témaköreihez: Ady Endre Fôvárosi Gyakorló Kollégium, Budapest, 2005. 249. p.). Ezzel az Ady a NTP által is preferált, ,jó gyakorlatok terjesztése” terén is élenjárónak mondható kollégium volt. E szakmai műhelyhez köthető a Kollégium c. folyóirat (1990) és a Kollégiumi Akadémia (2004) indulása is. Benedek I. (2002) id. m. 11spp. és http://ibenedic.hu/?page id=200 (utolsó lekérdezés: 2014. március 16.).
} 
pályázatokat, a harmadik egyszerre jeles tanuló, eredményes sportoló, néptáncos, s végül sikeres mérnök. Van, amelyiküknél az siker, hogy elmaradott kistelepülésről, iskolázatlan szülői háttérrel indulva főiskolai diplomát vagy kurrens szakmát szerez, másoknál a sikert évente több, országos tanulmányi versenyen besöpört dobogós helyezésben mérik. A tanár számára a legjólesőbb visszaigazolás azonban az, amikor e diákok évek múltán is visszatérnek különböző kollégiumi rendezvényekre vagy egyszerűen spontán beszélgetésre, nem elmulasztva felemlíteni, hogy az itt kapott segítség mennyire hasznos volt későbbi tanulmányaik során is. ${ }^{14}$

Tehetséggondozás és felzárkóztatás: e két fogalom alapvetően meghatározza a mai TMTK pedagógiai programját és szakmai hitvallását. A felzárkóztató, esélyteremtő és tehetséggondozó szakmai programok - különböző hangsúlyokkal - már a TMTK elődintézményei tevékenységét is jellemezték. Az egyesítés előtt - a tanulói összetételból és a kitűzött pedagógiai célokból fakadóan - a tantárgyi felkészítést a Rátz László (akkor: Latinka Sándor) utcai Diákotthonban a felzárkóztatás, a Táncsicsban a tehetséggondozás dominálta. A jelenleg múködő két tehetséggondozó szakmai program eredményességét az azokban résztvevő és onnan kikerülő növendékek tanulmányi sikerein és versenyeredményein túl az oktatáspolitika és a szakmai szervezetek elismerései igazolják vissza. ${ }^{15}$

\section{Speciális felvételi felkészítő program}

Intézményünkben a legnagyobb múltra visszatekintő tehetséggondozó-esélyteremtő szakmai programot tehát a speciális egyetemi-főiskolai felvételi felkészítô részleg (az egyszerűség kedvéért a továbbiakban: SPEC) képviseli. Szakmai programja és filozófiája az utóbbi években kevésbé változott, a kollégium szervezeti felépítésében játszott formális szerepe azonban átalakult. A kilencvenes években még a kollégium elkülönült, saját igazgatóhelyettes vezetésével, széleskörű belső intézményi autonómiát élvező részlegeként funkcionált, azóta azonban a TMTK szerves része, szakmai programként működik.

A SPEC kiemelt hangsúlyt fektet az emelt szintű tantárgyi felkészítésre, ám délutáni foglalkozásai deklaráltan csak kiegészítik, nem helyettesítik az iskolai tanítást. ${ }^{16} \mathrm{~A}$ fokozott szellemi igénybevétel megkívánja, hogy motivált és ambiciózus tanulók vegyenek részt a programban: ennek az a következménye, hogy a résztvevők jelentős hányada elit középiskolák diákja, eredménye pedig a kiemelkedően sikeres versenyeken és a kiugró felvételi mutatókon mérhető le. ${ }^{17}$

\footnotetext{
${ }^{14}$ Az AJTP számos kiemelkedő tehetségét - köztük TMTK-ban nevelkedettet is - mutatja be a nemrégiben megjelent „Aranykönyv”. Bővebben erről: Kovácsné Szeppelfeld E. (szerk.): Arany-könyv. Az. Arany János Tehetséggondozó Program intézményei és kiemelkedö tehetségei. É. n., k. n. (2013) 271. p.

15 Az utóbbi három évben három kolléga kapott szakmai elismerést: 2013-ban Csefkó Zoltán, a felvételi felkészítő részleg tanára miniszteri dicséretben részesült, míg Az Arany János Tehetséggondozó Programban dolgozó pedagógusok közül Pro Talento-dijas lett Tolnoi Róbert munkaközösség-vezető (2010) és Ringhofer Ervin általános igazgatóhelyettes, programgazda (2013).

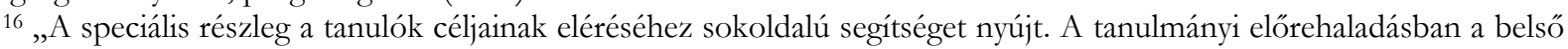
és a meghívott óraadó tanárok segítik őket. Az iskolai tanulmányokon túlmenően, azokra építve kiscsoportos felkészítés is folyik, amelyen minden tanuló az általa megcélzott pályairány tárgyainak megfelelően vesz részt." http://www.tankol.hu/tankol/tehetseggondozas/spec/ (2013. szeptember 6.).

${ }^{17}$ Uo. A sikeres felvételik aránya 90-100\% közötti, a végzősök jellemzően hazai és külföldi elit egyetemekre jutnak be. Mivel az alapozó tárgyakat (matematika és rokontudományai esetén, pl. lineáris algebra, analízis) jórészt már elsajátították, az egyetemen könnyebben is „maradnak meg”. Ezeken túl OKTV, OSZTV és más tantárgyi országos versenyek díjazottjai, matematika és fizika olimpiai válogatottak sora volt táncsicsos „speces” kollégista. (A legutóbbi, koppenhágai fizika diákolimpiára - egyedülálló módon - a két-két arany és ezüst, valamint egy bronzérmet szerzett ötfős magyar csapat két tagját is SPEC-es tanár készítette fel). (http://www.komal.hu/hirek/2013-

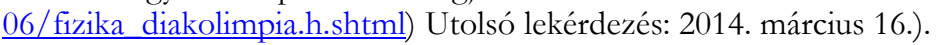


1. táblázat: A TMTK speciális felvételi felkészító squakeöreinek eredményessége (2007-2013) ${ }^{18}$

\begin{tabular}{|c|c|c|c|c|c|}
\hline helyezés & matematika & fizika & $\begin{array}{l}\text { kémia és } \\
\text { term.tud. }\end{array}$ & $\begin{array}{l}\text { informatika } \\
\text { és szakmai }\end{array}$ & $\sum$ \\
\hline & \multicolumn{5}{|c|}{ Nemzetközi tanulmányi versenyek (minősítések is) } \\
\hline 1. & 7 & 1 & 1 & - & 9 \\
\hline 2. & 1 & 1 & - & - & 2 \\
\hline 3. & 2 & 2 & - & - & 4 \\
\hline 4-10. & - & 1 & - & - & 1 \\
\hline \multirow[t]{2}{*}{ 11-20. } & - & 1 & - & - & 1 \\
\hline & \multicolumn{5}{|c|}{ Országos Középiskolai Tanulmányi Verseny } \\
\hline 1. & 2 & 1 & - & - & 3 \\
\hline 2. & - & - & 1 & - & 1 \\
\hline 3. & 1 & - & - & - & 1 \\
\hline 4-10. & 2 & - & 2 & 4 & 8 \\
\hline \multirow[t]{2}{*}{$11-20}$. & 1 & 1 & - & - & 2 \\
\hline & \multicolumn{5}{|c|}{ Egyéb országos tanulmányi versenyek } \\
\hline 1. & 7 & 3 & - & 1 & 11 \\
\hline 2. & 5 & 2 & 2 & - & 9 \\
\hline 3. & 5 & 4 & - & - & 9 \\
\hline 4-10. & 8 & 5 & 2 & - & 15 \\
\hline $11-20$. & 1 & 1 & - & - & 2 \\
\hline össz. & 42 & 23 & 8 & 5 & 78 \\
\hline átlag/év & 7,00 & 3,83 & 1,33 & 0,83 & 13 \\
\hline
\end{tabular}

(saját szerk.)

Módsz̧ertani összefoglalás gyanánt ismertetem a SPEC szakmai programjának legfontosabb elemeit.

- Két tantárgyból heti két-két óra emelt szintű szakkör.

- Negyedévente versenydolgozatok.

- Saját étékelési és ösztöndij-rendszer (2. ábra). ${ }^{19}$

- Kötelezően választott részvétel önképzőkörön.

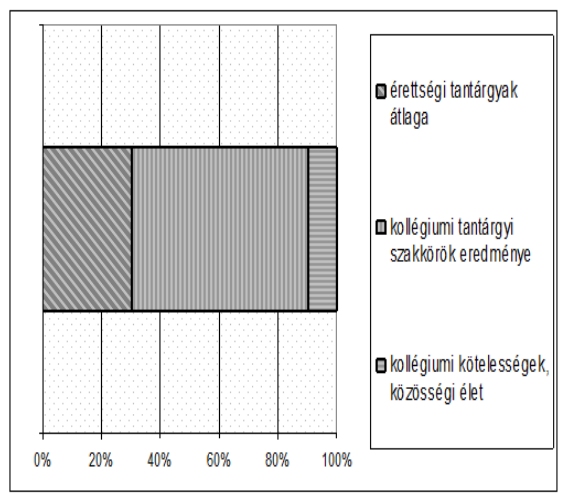

2. ábra: Az értékelési rendszer pontszámainak összetevőii a felvételi felkészító programban. ${ }^{20}$

(saját szerk.)

\footnotetext{
${ }^{18}$ Forrás: a tanulmányi versenyek és a TMTK adatbázisa, valamint Csefkó Zoltán portfoliója. Látható, hogy az iskolai felkészítés mellett a kollégiumi tehetséggondozó szakköröknek is jelentős szerepe van a kiemelkedő eredményesség (éves átlagban 13 versenyhelyezés) elérésében. A diákok versenyre felkészítő tanárként ez idő alatt 27 alaklommal nevezték meg kifejezetten a TMTK pedagógusát. Ez 35\%-os arány, de a többi 51 helyezést is olyan kollégista érte el, akinek felkészítése részben a TMTK tehetséggondozó szakkörein történt.

19 „A negyedéves értékelések az egyetemi felvételihez nélkülözhetetlen eredményeket összesítik egyetlen pontszámban.” http://www.tankol.hu/tankol/tehetseggondozas/spec/ (2013. szeptember 6.). „Az értékelés végeredménye az itteni élet minden területére hatással van, de két vonatkozásban, az ösztöndíj és a szabad mozgás (kimenő) meghatározásában döntő szerepet játszik.” (uo.). Az önképzőköri munkát, az írásos pályamunkákat és az országos versenyeredményeket a pontrendszer honorálja, míg az esetleges kollégiumi normaszegést (késést, igazolatlan mulasztást, a lakókörnyezet elhanyagolását) szankcionálja.

${ }^{20}$ A számított pontszám az értékelési, a kimenő- és az ösztöndijirendszer alapját képezi.
} 
A SPEC által tartott tantárgyi felkészítő szakkörök: matematika, fizika, analízis, lineáris algebra, idegen nyelv, történelem. Önképzőkörök a mindenkori diákok érdeklődési területeinek megfelelően és a tanári kapacitások függvényében szerveződnek (néhány ezek közül az elmúlt évekből: francia, török, spanyol, breton nyelv, bridzs, sakk, játékklub, újságírás stb.). Mindezeken túl a SPEC kapcsolódik a TMTK később bemutatott foglalkozási rendszeréhez.

Az elmúlt évek társadalmi és demográfiai változásainak bizonyos negatív hatásai alól ugyanakkor e program sem vonhatta ki magát. Miközben a TMTK férőhely-kihasználtsága évről-évre maximális vagy a közeli volt, a középiskolás diáklétszám csökkenése maga után vonta a „speces” diákok létszámának csökkenését (részben ez vezetett a részleg önállóságának megszűnéséhez is). A megoldás irányába a kitörési pont a belső nyitás volt: az utóbbi években a kollégium bármely növendéke részt vehetett a „speces” szakkörökön, sőt ösztöndíjat is kaphatott. További, újabb keletû gond a program finanszírozásának megoldatlansága, az ösztöndíjrendszer jövőjét illető bizonytalanságok, továbbá a programban oktató tanárok kis száma (emiatt a reáltudományágak erősebben reprezentáltak, mint a humán területek).

\section{Arany János Tehetséggondozó Program}

A TMTK az Arany János Tehetséggondozó Program (AJTP) alapító intézménye, tehát a kezdetektől, 2000-től vesz részt a programban. ${ }^{21}$ Az AJTP az első országos tehetséggondozó és esélyteremtő program, melyet 2004-ben a Hátrányos Helyzetű Tanulók Arany János Kollégiumi Programja (AJKP), 2008-ban a Halmozottan Hátrányos Helyzetű Tanulók Arany János Kollégiumi-szakiskolai Programja (AJKSzP) követett. ${ }^{22}$ A TMTK a Nemzeti Tehetség Programok rendszerébe mint regisztrált Tehetségpont kapcsolódik és a fent említettek közül az AJTP-ben vesz részt partneriskolájával, a budapesti Puskás Tivadar Távközlési Technikum Infokommunikációs Szakközépiskolával (PTTT).

Az Arany János Programok a mai Magyarország egyetlen, az állam teljes területére kiterjedô és legrégebben működő esélyteremtő és felzárkóztató szakmai programjait jelentik, az AJTP ezen belül a tehetséggondozást hivatott szolgálni. Kidolgozott és bejáratott módszertannal, kiépült intézményhálózattal rendelkezik.

A program főbb jellemzőinek vázlata: ${ }^{23}$

\section{a) A programba való bekerïlés feltétele:}

- pályázhat az a bármely okból hátrányos helyzetú nyolcadik osztályos tanuló, akinek életkörülményei nem teszik lehetôvé, hogy átlagon felüli képességeit kibontakoztassa;

- vagy: a szülők legfeljebb alapfokú iskolai végzettséggel rendelkeznek;

- vagy: jegyzố által védelembe vett vagy hátrányos helyzetủnek minősített gyermek;

- vagy: olyan gyermek, aki után önkormányzati határozat alapján rendszeres gyermekvédelmi támogatást folyósítanak.

\footnotetext{
21 Az Arany János Programok (AJP) jogszabályi alapját a 11/1994. (VI. 8.) MKM rendelet a nevelési-oktatási intézmények működéséről teremtette meg http://jogszabalykereso.mhk.hu/cgi bin/njt doc.cgi?docid=20252.585277 (utolsó lekérdezés: 2014. április 17.). A többször módosított jogszabály 39. \-ába az 1998-2002-es kormányzati ciklusban került kiegészítések indították el az AJP-at: az AJKP-ot és az AJKSzP-ot a 39/H §, az AJTP-ot a 39/I §. A 2000-ben az első Orbán-kormány által indított program jelenleg nagyrészt a 2006. májusi OM-dokumentum által ismertetett keretek között múködik. OM Közlemény a Hátrányos Helyzetű Tanulók Arany János Tehetséggondozó Programjáról. 2006. május 24., 10. p. www.nefmi.gov.hu/letolt/.../aitp palyazat om kozlemeny 070918.doc (utolsó lekérdezés: 2014. április 17.).

22 Mezei A., Polonkai M., Schmercz I.: Sajátos pedagógiai, pszichológiai ismeretek. BME GTK APPI Műszaki Pedagógiai Tanszék, Budapest, 2012. 64. p.

23 Tartózkodva a forrás szövegének beemelésétől, itt csak a program legfontosabb jellemzőit foglalom össze. Az AJTP kollégiumi foglalkozási és tevékenységi rendszeréről részletesen tájékoztat az 59/2013. (VIII. 9.) EMMI rendelet 4. számú melléklete. Az ott közöltek országosan egységesen kötelezőek a részt vevő intézményekre és diákokra, e dolgozatban a helyi sajátosságok bemutatására törekszem.
} 


\section{b) A bekerülés módja:}

- osztályfőnöki ajánlás és jellemzés;

- a küldő önkormányzat támogató nyilatkozata;

- az NTP programirodának megküldött jelentkezési lap (a tanuló önéletrajzával);

- a központi középiskolai felvételin való eredményes részvétel, ami kiegészül:

- az AJTP-hez kapcsolódó (közös iskolai-kollégiumi) felvételi elbeszélgetéssel;

- továbbá egységes logikai-pszichológiai teszt megírásával.

c) Az. AJTP fó célkitürése:

- Indulásakor: az ötezer főnél kisebb lakosságú településről származó diplomások aránya alulreprezentált e helységek népességének a teljes népességhez viszonyított hányadához képest. Ezt az arányt kívánta a kormányzat javítani a kistelepülésekről származó tehetségek felkarolásával (települési hátránykompenzáció). ${ }^{24}$

- Jelenleg: a tehetséges, de hátrányos helyzetű, nehéz sorsú fiatalok bejuttatása a felsôoktatásba oly módon, hogy az adott egyetemet vagy főiskolát el is tudják végezni, ne kallódjanak el. ${ }^{25}$ További cél, hogy a megszerzett versenyképes végzettséggel nőjenek elhelyezkedési esélyeik, életkörülményeik javuljanak. Társadalompolitikai cél a hátrányos helyzetű társadalmi réteg felemelkedésének elősegítése (társadalmi mobilitás; a hátrányos helyzet ne termelődjön újra).

\section{d) Az. AJTP által nyüjtott támogatás a hozott sqociokulturális hátrányok lekürdéséhę:}

- speciális tanterv, segítség az általános iskolából hozott tanulmányi lemaradás felszámolásához (előkészitő évfolyam emelt óraszámú idegen nyelv és informatikaoktatással);

- speciális tanterv és foglalkozási rendszer a középiskola öt évfolyamán: AJTP-blokk (tanulásmódszertan, humán kultúra-blokk, ön- és társismeret modul), munkamegosztásban az iskola és a kollégium között;

- a középfokú, államilag elismert nyelvvizsga térítésmentes megszerzésének támogatása;

- segítség a B kategóriás jármûvezetői engedély térítésmentes megszerzéséhez;

- a tanfolyam sikeres elvégzése után minden tanuló ECDL-bizonyítványhoz jut;

- önkormányzati ösztöndíjrendszer; ${ }^{26}$

- ingyenes kulturális és sportprogramok, tanulmányi kirándulások.

e) Az. AJTP finanszírozása:

- 2012-ig normatív rendszerben;

- jelenleg feladatfinanszírozás keretében. ${ }^{27}$

\section{f) Az. AJTP helyi sajátosságai:}

\footnotetext{
${ }^{24}$ Ezt - az azóta eltörölt - követelményt felülírták a szociális szempontok, így már nagyvárosi, sőt budapesti tanulók is felvételt nyerhetnek.

25 A középiskolákból kilépók életpálya-követése fontos feladat. A felsőoktatásban a NTP-hez kapcsolódó mentorprogramok feladata. A tehetségsegítők, pedagógusok - az alapfokú intézményektől a felsőoktatásiig ívelőszakmai és anyagi támogatására jött létre a Magyar Géniusz Program. (Polonkai M. et al. Id. m. 72. p). Folytatása a már említett Tehetséghidak, a jövőben pedig a Talentum Program.

26 Sajnos ennek biztosítását egyre több (többnyire maga is önhibáján kívül hátrányos helyzetű, kistelepülési) önkormányzat képtelen vállalni.

${ }^{27}$ Oly módon, hogy a központi költségvetés a Klebelsberg Intézményfenntartó Központ (KLIK) részére elkülönítetten biztosít 2,7 milliárd forintot a különböző tehetséggondozó programok finanszírozására - Marekné dr. Pintér Aranka, a KLIK akkori elnökének szóbeli bejelentése az AJTP XIII. Országos Konferenciáján, Budapesten (2013. március 19.).
} 
- folyamatos tanári felügyelet és differenciált szaktárgyi segítségnyújtás a kollégiumban is;

- a programot két önálló intézmény (iskola és kollégium) működteti, melyek között folyamatos és élő kapcsolat, szakmai egyeztetés és munkamegosztás van. A program TMTK szervezésében megvalósuló főbb elemei:

- a testi-lelki egészség harmonikus egységének hangsúlyos volta: egészséghét, felvilágosító programok és előadások, védőoltások (influenza, HPV), a sport kiemelt szerepe, elsősorban:

- úszásoktatás, korcsolya- és uszodabérletek, sítáborok, műfüves futball;

- AJTP tanulmányi feladatok átvállalása a PTTT'tól: szaktárgyi felzárkóztató és korrepetálás a TMTK foglalkozási rendjébe illeszkedően; külön AJTP angol nyelvi órák az iskolai csoportbontásoknak megfelelően; az AJTP-blokkból a tanulásmódszertan, ön- és társismeret foglalkozásai a TMTK-ban, a kollégium tanáraival történik;

- havonta egy kollégiumi hétvége tanulmányi és személyiségfejlesztô foglalkozásokkal, szabadidôs, sport- és kulturális programokkal;

- kül- és belföldi tanulmányi kirándulások szervezése.

\section{A Táncsics Mihály Tehetséggondozó Kollégium foglalkozási rendszere}

Az előzőekben bemutatott tehetséggondozó és felzárkóztató programok az intézmény foglalkozási rendszerébe illeszkedve, a jogszabályok betartásával működnek.

A kollégium foglalkozási rendszere megfelel a Nemzeti kollégiumi alapprogram elvárásainak és előírásainak. Integrálja a tehetséggondozó programokat, de működési köre szélesebb azoknál, hiszen a hagyományos tanulássegító és a szabadidős tevékenységeket is magába foglalja. A kollégiumi tevékenységek rendszerében megkülönböztetünk irányított (a személyiség fejlődéséhez szükséges, általában szabadidős jellegú, ám tanári ráhatás nélkül a diákok által esetleg nem vagy nem szívesen választott), kötött (többnyire tantárgyi jellegű) és kötetlen tevékenységeket (BENEDEK I., 2002). Előbbi kettő az intézmény formalizált foglalkozási rendszerének részét képezi, utóbbi a tanuló által szabadidejében, szabályozástól csaknem mentesen végzett időtöltések összefoglaló neve. ${ }^{28}$

A kollégiumi alapprogram ugyanezt a kategorizálást úgy végzi el, hogy a kötetlen tevékenységek kihagyásával, a kötött és irányított tevékenységekre összpontosít a foglalkozások részletezésénél; ú.m. tanulást segítő, egyéni és közösségi fejlesztést megvalósító, továbbá a szabadidő eltöltését szolgáló foglalkozások.

A TMTK foglalkozási rendszerének kialakításánál alapelv volt az átjárhatóság megteremtése: ennek megfelelően a felvételi felkészítő szakköröket az AJTP tanulói vagy az érettségi utáni képzésben részt vevôk is látogathatják. ${ }^{29} \mathrm{Az}$ intézményben nem lezárt pedagógiai vita tárgya, hogy a kötött tanulószoba és a tantárgyi foglalkozások mennyire legyenek hangsúlyosak a foglalkozási rendszerben: a kollégák egy része ellenzi az ,iskola a kollégiumban” jelleget (vö. BENEDEK I. 2002), mások a hagyományaink részének tekintik és a megtartás mellett vannak. Helyes és kívánatos megoldás minden bizonnyal az arany középút, ahol a kötött, az irányított és a kötetlen tevékenységek harmonikus arányban, egymást kiegészítve képezik a kollégium tevékenységportfolióját. A TMTK tantárgyi foglalkozási rendszerét az 2. táblázat, a teljes foglalkozási spektrumot és a Nemzeti kollégiumi alapprogrammal való kompatibilitást a 3. táblázat szemlélteti.

\footnotetext{
${ }^{28}$ Benedek I. (2002) id. m. 67spp.

${ }^{29}$ Fordított irányban ez az átjárás már korlátozottabb, aminek oka az AJTP szoros elszámolási kötelezettsége: az „aranyos” rendezvényeken való részvétel - nem AJTP-tanulók számára - csak a jogszabályi előírásokat nem sértő mértékben lehetséges (pl. tanulmányi kirándulásokhoz csatlakozás önköltségi alapon).
} 
2. táblázat: A Táncsics Mihály Tehetséggondozó Kollégium tantárgyi foglalkozásainak rendszere

\begin{tabular}{|l|l|l|l|l|l|l|l|l|l|l|l|}
\hline & A & B & C & D & E & & A & B & C & D & E \\
\hline $\begin{array}{l}\text { Magyar nyelv és } \\
\text { irodalom }\end{array}$ & $\mathrm{X}$ & $\mathrm{X}$ & $\mathrm{X}$ & $\mathrm{X}$ & & Angol nyelv & & $\mathrm{X}$ & $\mathrm{X}$ & $\mathrm{X}$ & $\mathrm{X}$ \\
\hline $\begin{array}{l}\text { Olvasásfejlesztés- } \\
\text { szövegértés }\end{array}$ & $\mathrm{X}$ & $\mathrm{X}$ & & & & Német nyelv & & $\mathrm{X}$ & $\mathrm{X}$ & & \\
\hline Történelem & $\mathrm{X}$ & $\mathrm{X}$ & $\mathrm{X}$ & $\mathrm{X}$ & $\mathrm{X}$ & Francia nyelv & & & $\mathrm{X}$ & & \\
\hline Matematika & $\mathrm{X}$ & $\mathrm{X}$ & $\mathrm{X}$ & $\mathrm{X}$ & $\mathrm{X}$ & Orosz nyelv & & & $\mathrm{X}$ & & \\
\hline Fizika & & & $\mathrm{X}$ & $\mathrm{X}$ & $\mathrm{X}$ & Spanyol nyelv & & & $\mathrm{X}$ & $\mathrm{X}$ & \\
\hline Kémia & & & $\mathrm{X}$ & $\mathrm{X}$ & & Elektrotechnika & & $\mathrm{X}$ & $\mathrm{X}$ & & \\
\hline Biológia & & & $\mathrm{X}$ & & & Programozás & & & & & $\mathrm{X}$ \\
\hline Földrajz & & & $\mathrm{X}$ & $\mathrm{X}$ & & Analízis & & & & & $\mathrm{X}$ \\
\hline Környezetvédelem & & & & & $\mathrm{X}$ & Algebra & & & & & $\mathrm{X}$ \\
\hline
\end{tabular}

A: felmérés (tanév elején), B: felzárkóztató (tanév eleji felmérés alapján), C: korrepetálás (igény és eredmény szerint), D: érettségi felkészítő szakkör (jelentkezés alapján), E: tehetséggondozó szakkör (jelentkezés alapján).

(RINGHOFER E. 2014 alapján, módositva).

\section{3. táblázat A Táncsics Mihály Tehetséggondozó Kollégium foglalkozási rendszere}

\begin{tabular}{|c|c|c|c|}
\hline $\begin{array}{l}\text { Foglalkozás megnevezése } \\
\text { (59/2013 EMMI r. 1. sz. } \\
\text { melléklet) }\end{array}$ & $\begin{array}{l}\text { Munkaforma és a } \\
\text { résztvevők köre (TMTK) }\end{array}$ & $\begin{array}{l}\text { Foglalkozási } \\
\text { óraszám/hét }\end{array}$ & Megjegyzés \\
\hline \multicolumn{4}{|c|}{ 1. Tanulást segítő foglalkozások } \\
\hline $\begin{array}{l}\text { a) rendszeres iskolai felkészülést } \\
\text { biztosító egyéni és csoportos } \\
\text { foglalkozás, } \\
\text { b) differenciált képességfejlesztő, } \\
\text { tehetség-kibontakoztató foglalkozás, } \\
\text { c) a bármely okból lemaradó tanulók } \\
\text { felzárkóztatása, } \\
\text { hátránykompenzáció, } \\
\text { d) a tantárgyi ismeretek bővítése és a } \\
\text { pályaválasztás segítése érdekében } \\
\text { szervezett szakkörök, diákkörök, } \\
\text { e) tematikus csoportfoglalkozás. }\end{array}$ & $\begin{array}{l}\text { a) tanulószoba } \\
\text { b) tantárgyi szakkörök, } \\
\text { versenffelkészítés } \\
\text { ca) felzárkóztató } \\
\text { (csoportos) } \\
\text { cb) korrepetálás (1-3 fö) } \\
\text { d) szakkörök (érdeklődési kör } \\
\text { szerint) } \\
\text { da) középszintű érettségire } \\
\text { felkészítő } \\
\text { db) emelt szinten felkészítő } \\
\text { dc) diákkör, önképzőkör } \\
\text { e) tematikus csoportfoglalkozás } \\
\text { 1. témakör }\end{array}$ & $\begin{array}{l}\text { max. } 15 \\
\text { 2/szakkör } \\
1-2 \\
1-3 \\
2 \text { /szakkör }\end{array}$ & $\begin{array}{l}\text { eredmény } \\
\text { alapján } \\
\text { jelentkezés } \\
\text { alapján } \\
\text { felmérés } \\
\text { alapján } \\
\text { isk. eredm. } \\
\text { szerint } \\
\text { jelentkezés } \\
\text { alapján } \\
\text { kötelező }\end{array}$ \\
\hline \multicolumn{4}{|c|}{ 2. Egyéni és közösségi fejlesztést megvalósító foglalkozások } \\
\hline $\begin{array}{l}\text { 1. Csoportvezetóí foglalkozások: } \\
\text { a) közösségi foglalkozás a kollégiumi } \\
\text { csoportok számára: } \\
\text { a csoport életével kapcsolatos } \\
\text { feladatok, tevékenységek, } \\
\text { események, problémák } \\
\text { megbeszélése, értékelése } \\
\text { b) tematikus csoportfoglalkozások: } \\
\text { az e rendeletben előírt témakörök, } \\
\text { időkeretek között szervezhetô } \\
\text { foglalkozások } \\
\text { 2. A kollégiumi közösségeke szervezésével } \\
\text { összefüggó foglalkozások: } \\
\text { a) a kollégiumi diákönkormányzatok } \\
\text { múködésének támogatása }\end{array}$ & 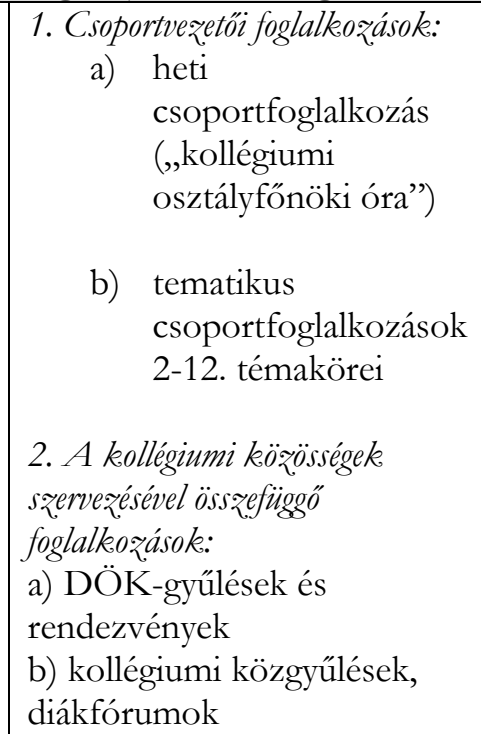 & $\begin{array}{l}1 \\
2 / \operatorname{tanév}\end{array}$ & $\begin{array}{l}\text { Kötelező, az } \\
\text { adott csoport } \\
\text { vezetője tartja. } \\
\text { Kötelező, } \\
\text { témakörönként } \\
\text { más-más tanár } \\
\text { tartja. } \\
\text { Gólyatábor, } \\
\text { kollégiumi hét, } \\
\text { farsang, } \\
\text { gyermekhét } \\
\text { stb. }\end{array}$ \\
\hline
\end{tabular}




\begin{tabular}{|c|c|c|c|}
\hline $\begin{array}{l}\text { b) kollégiumi diákfórumok } \\
\text { (kollégiumi gyúlés, kisebb } \\
\text { közösségek szerinti megbeszélések) } \\
\text { 3. A tanulókkal való egyéni töródést } \\
\text { biz̧tositó foglalkozások: } \\
\text { a foglalkozásokon (tanulói vagy } \\
\text { pedagógusi kezdeményezésre) a } \\
\text { diákok feltárhatják egyéni } \\
\text { problémáikat } \\
\text { ezek megoldásában számíthatnak a } \\
\text { pedagógus tanácsaira, segítségére }\end{array}$ & & & \\
\hline \multicolumn{4}{|c|}{ 3. Szabadidő eltöltését szolgáló foglalkozások ${ }^{30}$} \\
\hline $\begin{array}{l}\text { Állandó, vagy adott eseményre } \\
\text { szerveződő kollégiumi } \\
\text { diákcsoportok számára szervezett } \\
\text { - irodalmi, képzőmûvészeti, zenei, } \\
\text { tánc, vizuális képességeket fejlesztő } \\
\text { mûvészeti, } \\
\text { - természettudományos, műszaki, } \\
\text { vállalkozói, gazdasági ismereteket } \\
\text { bővítő szakmai, } \\
\text { - egészséges életmódra nevelést, a } \\
\text { rendszeres testedzést szolgáló } \\
\text { sportcélú, } \\
\text { - a hasznos gyakorlati ismeretek } \\
\text { megszerzését, az önellátás } \\
\text { képességének fejlesztését célzó, } \\
\text { - a pályaorientáció szempontjából is } \\
\text { fontos tartalmakat hordozó, } \\
\text { szakkörök, szakmai, múvészeti } \\
\text { foglalkozások, kollégiumi } \\
\text { sportkörök, rendezvények, } \\
\text { versenyek, vetélkedők. }\end{array}$ & $\begin{array}{l}\text { - } \quad \text { táncoktatás (AJTP } \\
\text { szalagavató) } \\
\text { - múzeumlátogatás, } \\
\text { kiállítások } \\
\text { - házi } \\
\text { sportbajnokságok } \\
\text { (labdarúgás, } \\
\text { kosárlabda, } \\
\text { strandröplabda, } \\
\text { asztalitenisz, fittségi } \\
\text { versenyek stb.) } \\
\text { múfüves } \\
\text { futballpálya-, } \\
\text { korcsolya és } \\
\text { uszodabérlet } \\
\text { kézmúves-szakkör } \\
\text { játékklub } \\
\text { filmklub } \\
\text { - gólyatábor, } \\
\text { egészséghét, } \\
\text { kollégiumi hét, } \\
\text { farsang, gyermekhét, } \\
\text { Erzsébet-tábor }\end{array}$ & $\begin{array}{l}\text { változó } \\
\text { alkalmi } \\
\text { rendszeres } \\
\text { igény szerint } \\
2 \\
2 \\
2 \\
\text { rendszeres } \\
(\text { évente 1-2) }\end{array}$ & $\begin{array}{l}\text { Kötelezően } \\
\text { választható } \\
\text { legalább egy. }\end{array}$ \\
\hline
\end{tabular}

\section{Esélyteremtés és tehetséggondozás mint a kollégium szervezeti kultúrájának, pedagógiai arculatának központi eleme}

Nézetem szerint kívánatos, hogy a - felzárkóztatást és tehetséggondozást egyaránt magába foglaló - esélyteremtés minden középiskolai kollégium pedagógiai küldetésének alappillére legyen. Ez az elméleti elvárás azonban nem minden esetben van összhangban a gyakorlati lehetőségekkel: az esélyteremtő pedagógiai környezet megteremtése a korábban említett kollégiumtípusok mindegyikében vagy nagy többségében elérhető, annak teljes, a tehetséggondozást is magában foglaló spektruma azonban leginkább a speciális és a szakkollégiumokban válhat valós gyakorlattá. ${ }^{31}$

\footnotetext{
30 Az 59/2013 (VIII. 30.) sz. miniszteri rendelet előírásainak megfelelően, fentieken kívül, tanév elején minden kollégista választ egy -heti egy óra kötelező elfoglaltságot jelentő- szabadidős foglalkozást. A TMTK „kínálata” a 2014/2015-ös tanévben közel 60 féle kötelezően választandó szabadidős foglalkozásból állt.

${ }^{31}$ Ennek ugyanis objektív kritériumai vannak: ilyen a megfelelő tárgyi-technikai környezet, a szakos ellátottság és a pedagógusok módszertani repertoárjának, pedagógiai kultúrájának, (tovább)képzettségének magas színvonala, a kimunkált és gyakorlatban is megvalósított pedagógiai program.
} 
A TMTK rendelkezik azokkal az objektív feltételekkel, amelyek lehetővé tették, hogy a magyar tehetséggondozó hálózat és a fővárosi középiskolai kollégiumi rendszer, összességében a társadalmi mobilitást elősegítő hazai intézményrendszer fontos elemévé váljon. Az esélyteremtô szakmai programok egyaránt beépültek a kollégium szervezeti kultúrájába és pedagógiai arculatába. ${ }^{32}$

A hatályos jogszabályok (főként a Kollégiumi nevelés országos alapprogramja) által meghatározott foglalkozási rendszernek a TMTK tehetséggondozó programjai megfelelnek, azzal kompatibilisek. A két tehetséggondozó program a kollégium foglalkozási rendszerébe illeszkedve meghatározza az intézmény pedagógiai arculatát. Az itt dolgozó, mesterségüket hivatásnak tekintő pedagógusok hiszik, hogy e pedagógiai arculat - a szervezeti kultúra fontos alkotóelemeként szerves része a Táncsicsról a külső szemlélő (a „megrendelők”: a diákok és a szülők), valamint a szakmai partnerek szemében kialakult képnek.

\section{Irodalom}

Benedek István (1997): Kollégiumi neveléstan. A kollégiumi nevelés elmélete és gyakorlata. Országos Közoktatási Intézet, Budapest. 312. p

Benedek István (1993): Kollégiumpedagógia. Tanulmányok a kollégiumi nevelés témaköréböl. Zánka.

Benedek István (2013): A közoktatási intézmény hatékonysága. „B” rész: BME GTK APPI Műszaki Pedagógiai Tanszék, Budapest, 116. p.

Benedek István (2012): Közoktatás-rendszer- és szervezettan. „B” rész: Szervezettan. BME GTK APPI Műszaki Pedagógiai Tanszék, Budapest, 105. p.

Benedek István (2011): Pedagógus szerepváltozások. Az intézményvezetés kompetenciaalapú megközelitése. PPT-bemutató, Ady Endre Közgazdasági Szakkollégium, Budapest, 42. p.

Benedek István (sžerk.) (2006): Gondolatok a kollégiumban III. A minöségfejlesz̨tés, a minöségbiztositás a kollégiumi oktató-nevelö munkea gyakorlatában.. Ady Endre Fővárosi Gyakorló Kollégium, Budapest, 279. p.

Czeizel Endre (2004): Sors és tehetség. Urbis, 242. p.

Inántsy-Pap Judit-Orosz Róbert-Pék Győző-Nagy Tamás (2010): Tehetség és szuemélyiségfejlesztés. Magyar Tehetségsegítő Szervezetek Szövetsége. 139. p.

Kovácsné Szeppelfeld Erzsébet (szerk.) (2013): Arany-könyv. Az Arany János Tehetséggondozó Program intézményei és kiemelkedő tehetségei. 271. p.

Mezei Anna-Polonkai Mária-Schmercz István (2012): Sajátos pedagógiai, pszichológiai ismeretek. BME GTK APPI Műszaki Pedagógiai Tanszék, Budapest, 161. p, (2.3.4. Hazai tehetséggondozás, tehetséggondozó programok).

Ringhofer Ervin (2014): Tehetségmodell a Táncsics Mihály Tehetséggondoró Kollégiumban - Út a sqakkollégium felé. Előadás, elhangzott a Tehetséghidak Program Tudástranszfer Fórumán. TÁMOP 3.4.5, Szeged, 2014. március 11.

Rogers, Carl R.-Freiberg, H. Jerome (2007): A tanulás sqabadsága. EDGE 2000 Kiadó Oktatáskutató és Fejlesztő Intézet, Budapest, 596. p.

Simon István (1998): Kollégiumtörténeti vázlatok és tanulmányok. UnivPress, Budapest.

\footnotetext{
32 Az előző fejezetekben részletezett tényeken túl bizonyítja ezt, hogy a TMTK és tanárai (előadóként is) részt vesznek az országos szakmai fórumokon, továbbképzéseken; tagjai szakmai szervezeteknek; óraadó tanárok több, elismert és eredményes tehetséggondozó iskolában (pl. Budapesti Fazekas Mihály Gimnázium); az intézményben rendszeresen jó gyakorlat és ismeretátadó műhelytevékenység folyik (pl. AJTP országos kollégiumi munkaközösség).
} 
Internetes források

Balogh László (2007): Elméleti kïndulási pontok a tehetséggondozó programokhoz. A Nemzeti Tehetségsegítő Tanács 2007. január 5-6-i tanácskozása. Mi a tehetség? http://tehetseg.hu/mitehetseg (utolsó lekérdezés: 2014. március 16.).

A KöMaL versenyzőinek sikeres sqereplése a 2013. évi Fiquika Diákolimpián. (Lekérdezés: 2013. szeptember 6.) http://www.komal.hu/hirek/2013-06/fizika diakolimpia.h.shtml

Tóth Tamás (2014): A bazai tehetséggondozás belyzete, intérményi feladatok. Előadás, elhangzott a Tehetséghidak Program Tudástranszfer Fórumán. TÁMOP 3.4.5, Szeged, 2014. március 11.

http://tehetseg.hu/ (utolsó lekérdezés: 2014. március 16.).

Jogszabályi források

11/1994. (VI. 8.) MKM rendelet a nevelési-oktatási intérzmények müködéséról.

http://jogszabalykereso.mhk.hu/cgi bin/njt doc.cgi?docid=20252.585277 (utolsó lekérdezés: 2014. április 17.).

1993. évi LXXIX. törvény a közoktatásról.

http://net.jogtar.hu/jr/gen/hjegy doc.cgi?docid=99300079.TV (utolsó lekérdezés: 2013. szeptember 30.)

2011. évi CXC. törvény a nemzeti köznnevelésröl. Magyar Közlöny, 2011. évi 162. szám, 39622-39695. p.

20/2012. (VIII. 31.) EMMI rendelet a nevelési-oktatási intézmények müködéséröl és a köznevelési intézmények névhasználatáról. Magyar Közlöny, 2012. évi 115. szám, 19493-19641. p.

229/2012. (VIII. 28.) kormányrendelet a nemzeti köznevelésröl szóló törvény végrehajtásáról. Magyar Közlöny, 2012. évi 112. szám, 19043-19094. p.

46/2013. (VII. 4.) EMMI rendelet az. Arany János Tehetséggondozó Program, az. Arany János Kollégiumi Program és az. Arany János Kollégiumi-Szakiskolai Program támogatásának igénylése, döntési rendszere, folyósitása, elszámolása és ellenörzése részletes szabályairól. http://net.jogtar.hu/jr/gen/hjegy doc.cgi?docid=A1300046.EMM (utolsó lekérdezés: 2014. április 17.).

59/2013. (VIII. 9.) EMMI rendelet a kollégiumi nevelés országos alapprogramjának kiadásáról. Magyar Közlöny, 2013. évi 133. szám 65488-65585. p.

www.ajtp.hu (Lekérdezés: 2013. szeptember 6.)

OM Közlemény a Hátrányos Helyzetú Tanulók. Arany János Tehetséggondozó Programjáról. 2006. május 24. 10p. www.nefmi.gov.hu/letolt/.../ajtp palyazat om kozlemeny 070918.doc (utolsó lekérdezés: 2014. április 17.).

A Táncsics Mibály Kollégium minöségirányitási programja. Budapest, 2009. 60. p. http://tankol.hu/tankol/dokumentumok/MIN $\%$ C5\% $\% 0$ S $\%$ C $3 \% 89$ GIR $\% \mathrm{C} 3 \% 81 \mathrm{NY} \% \mathrm{C} 3 \% 8$ DT\%C3\%81SI\%20PROGRAM\%202009.pdf (utolsó lekérdezés: 2013. október 3.)

A Táncsics Mihály Tehetséggondozó Kollégium pedagógiai programja. Budapest, 2010. 87. p.

A Táncsics Mihály Tehetséggondozó Kollégium pedagógiai programja. Budapest, 2013. 99. p.

A Táncsics Mibály Tehetséggondozó Kollégium Szuervezeti és Múkeödési Szabályzata. Budapest, 2011. 37. p. és mellékletek. 